UDC 614.78

DOI: $10.21668 /$ health.risk/2020.3.03.eng

Research article

\title{
CONTEMPORARY CHALLENGES AND WAYS TO IMPROVE HEALTH RISK ASSESSMENT AND MANAGEMENT
}

\author{
V.N. Rakitskii, S.V. Kuz'min, S.L. Avaliani, T.A. Shashina, N.S. Dodina, V.A. Kislitsin \\ Federal Research Center of Hygiene named after F.F. Erisman, 2 Semashko Str., Mytishchi, 141014, Russian Federation
}

\begin{abstract}
We analyzed basic trends in improving risk assessment and management in Russia taking into account international experience; these trends arise from needs occurring in contemporary hygienic science and necessity to provide stronger resistance against new threats to population health.

We substantiated specific tasks in development of health risk analysis mythology basing on preconditions for finding solutions to them in Russia; we also determined practical issues in its implementation that are the most vital and need solutions in the nearest future in order to eliminate adverse impacts on the environment and population health.

The primary results are creation of a long-term strategy for the development of health risk analysis principles that takes into account the latest scientific data and is aimed at solving the following methodological and practical tasks: implementation of a systemic approach in estimating carcinogenic / non-carcinogenic risks; development of a unified approach to accomplishing toxicological «dose - response» examinations and interpreting their results which will take into account background morbidity and background dose burdens and determine susceptible population groups and behavioral models; threshold levels obtained via determining «benchmark» concentrations taking spontaneous background into account in order to determine new RfD and RfC and revise existing ones; use of micro-environmental approach in exposure estimation; use of risk assessment methodology in BAT parameters implementation for providing control over health safety after new approaches aimed at reducing emissions have been implemented in environmental protection. The necessity to improve approaches to health risk assessment and management and tasks solved within the process have been taken into account when the Branch scientific research program for 2021-2025 was developed by Rospotrebnadzor.

Key words: risk assessment, risk management, population health, environment, carcinogenic and non-carcinogenic effects, dose - response, micro-environment exposure, BAT.
\end{abstract}

Nowadays health risk assessment and management are being given a lot of attention by experts from various spheres as their results underlie significant processes both in economically developed and developing countries. These processes are further development of regulatory and legal documents and methodical guidelines and substantiation of managerial decisions. Bearing in mind a wide range of possibilities for applying health risks assessments, validity of their results is being thoroughly analyzed by scientists, economists, politicians, and the society as a whole.

Scientific grounds for risk assessment have changed considerably over the last 15-20 years; they follow a common trend for things getting more complex in those spheres of

(C) Rakitskii V.N., Kuz'min S.V., Avaliani S.L., Shashina T.A., Dodina N.S., Kislitsin V.A., 2020

Valerii N. Rakitskii - Doctor of Medical Sciences, Professor, RAS Academician, Scientific supervisor at the Institute for Hygiene, Toxicology and Pesticides, and Chemical Safety (e-mail: pesticidi@fferisman.ru, rakitskiivn@fferisman.ru; tel.: +7 (495) 586-11-44; ORCID: http://orcid.org/0000-0002-9959-6507).

Sergei V. Kuz'min - Doctor of Medical Sciences, Professor, Director (e-mail: kuzminsv@fferisman.ru; tel.: +7 (495) 586-11-44; ORCID: http://orcid.org/0000-0002-9119-7974).

Simon L. Avaliani - Doctor of Medical Sciences, Professor, Head of the Health Risk Analysis Department (e-mail: avalianisl@fferisman.ru; tel.: +7 (495) 586-11-44; ORCID: http://orcid.org/0000-0002-3113-7101).

Tat'yana A. Shashina - Candidate of Medical Sciences, Leading researcher at the Health Risk Analysis Department (e-mail: shashinata@fferisman.ru, sta815@mail.ru; tel.: +7 (495) 586-11-44; ORCID: http://orcid.org/0000-0002-4190-0326).

Natalia S. Dodina - Candidate of Medical Sciences, Leading researcher at the Health Risk Analysis Department (e-mail: dodinans@fferisman.ru, skvnata@mail.ru; tel.: +7 (495) 586-11-44; ORCID: http://orcid.org/0000-0001-6693-922X).

Victor A. Kislitsin - Candidate of Technical Sciences, Senior researcher at the Health Risk Analysis Department (e-mail: kislitsinva@fferisman.ru; tel.: +7 (495) 586-11-44,+7 (916) 872-94-58; ORCID: http://orcid.org/0000-0002-6575-2882). 
knowledge with progress made in them being actively used in risk analysis methodology.

Risk assessment procedures are being implemented into practice at present; however, we can't see substantial progress in methodology development in many spheres.

Development of analytic research procedures allows scientists to concentrate on finding solutions to fundamental issues related to improvement of risk analysis methodology.

An issue that yet remains unresolved is methodical approaches to assessing combined and complex effects produced on a body by multiple chemicals; taking into account person's individual sensitivity; a probability to assess different factors (chemical, physical, and biological ones) that produce combined effects.

In Russia there is certain background for further development in some research spheres mentioned above. Practically from the very beginning of methodology implementation experts have been taking into account a hazard that influencing compounds would produce toxic effects on critical organs and systems and/or a carcinogenic hazard using the most conservative summation principle. Still there has been no detailed research on where adverse chemical impacts exerted by different substances would localize depending on their peculiar behavior in an influencing medium and in a body; nowadays it is becoming an obligatory condition for application of up-to-date risk assessment.

Combined assessment of different risks is based on searching for and applying similar potential effects on exposed population health. For example, radiation factor can produce effects similar to those produced by chemical carcinogens as well as by ambient air contamination in urban settlements (nitrogen and sulfur dioxides, carbon oxide, ozone, and particulate matter including fine-disperse fractions $\mathrm{PM}_{10}$ and $\mathrm{PM}_{2,5}$ ) that are proven by epidemiologists to cause deaths and hospitalizations in a population in addition to background levels.

An algorithm for comparative assessment of radiation and chemical risks has been developed basing on long-term experience in studying similar consequences of exposure to radiation and chemical environmental factors $[1,2]$.

Another example of examining and taking into account combined effects produced on population by risk factors that are different in their nature is a study on exposure to high air temperature and ambient air contamination and its influence on population mortality with building an epidemiologic model exemplified with an emergency situation that occurred in Moscow city and the Moscow Area in summer 2010 [3].

But still there is a necessity to apply health risk assessment in a wider sense in order to find solutions to some complex tasks such as analysis of a substance or a product life cycle; scientific substantiation for economic cost estimate or advisability to replace one risk with another etc.

In order to improve health risk assessment procedures accepted by Rospotrebnadzor, concrete actions are going to be required. Let us stress that suggested measures are to provide more profound application of the latest scientific data in risk assessment and to make its results more useful for political decision-making. A necessity to modernize risk assessment requires a long-term strategy based on the existing methodology but at the same time it will be necessary to intensify coordination and information exchange between Rospotrebnadzor's institutions and bodies and to provide training and skills development for Rospotrebnadzor personnel. This new strategy should be based on executive authorities themselves being ready to implement risk assessment into decision-making and it should be both fixed in regulatory and legal documents and implemented into practice.

Today, risk assessment should become a procedure for assessing relative advantages of different risk management techniques and not be a goal in itself; it can be reached only provided that clear unambiguous risk management goals and tasks are set as they are the primary reason for health risks assessment to be performed at all. 
A change in the existing views on risk assessment can raise its influence on decisions being made as the suggested measures envisage the leading role of the careful and correct planning aimed at making risk assessment truly vital in finding solutions to concrete problems when risk assessment results are to be applied for informing decision-makers on a range of solutions available to them taking into account economic and social benefits [4-6].

Since at present results of epidemiologic research and «dose/concentration - response» dependences determined on their basis are not sufficiently applied for comprehensive assessment of damage to health, it is extremely vital to make the process more active [7]. It is possible to obtain necessary data via implementing activities included into «Clean air» Federal program which is a part of «Ecology» National project ${ }^{1}$.

A substantial contribution into health risk analysis improvement is made by finding a solution to a task on creating a unified approach to assessing «dose - response» dependence regarding carcinogenic and non-carcinogenic effects based on the latest scientific data. We should bear in mind that at present risk assessment entails different approaches to characterizing risks of carcinogenic and non-carcinogenic effects, and considerably less attention is paid to non-carcinogenic effects occurrence. Reference doses / concentrations (RfD/RfC) can't be considered a proper measure for quantitative risk assessment under different exposure levels; therefore, their application in comparative risk assessment and in economic costs and benefits analysis is considerably limited. Carcinogenic risk assessment usually doesn't take into account any differences between different people regarding an extent to which they are predisposed to oncologic diseases excluding probable difference existing at early stages of life.

Scientific considerations and risk management requirements predetermine a trend for unifying approaches to carcinogens and noncarcinogens when it comes to assessing «dose response» dependences under low doses [8-11]. It is recommended to develop a unified approach to modeling «dose - response» assessment that should be based on systemic taking into account several vital parameters such as background morbidity and background dose burdens; differences in behavioral patterns; probable existence of susceptible population groups. Failure to take them into account can result in differences in individual «dose - response» profiles. World scientific society suggests a new concept of RfD/RfC values defining them as a risk-specific dose showing a share of population that is above and below a determined acceptable risk level with a certain degree of authenticity.

In the nearest future it is especially vital to perform toxicological studies aimed at determining threshold levels for substantiating $\mathrm{RfD} / \mathrm{RfC}$ basing on «benchmark» concentrations taking into account spontaneous background and not only thresholds calculated with conventional procedures involving NOAEL/LOAEL determination [12].

Implementation of approaches into health risk assessment that take into account microenvironment influence will allow more profound assessment of population exposure and obtaining more valid results. A micro-environment in risk assessment methodology is a specific space in the environment where a person contacts some adverse substances. A microenvironment should be a homogenous space as regards contamination at a specific moment of time and should be characterized with contaminants concentrations with sufficiently low uncertainty. A typical micro-environment is an apartment, an office, a classroom, a workshop, a street, a vehicle etc. When assessing risks taking into account micro-environments, overall dose burden is calculated as a sum of doses

\footnotetext{
${ }^{1}$ «Ecology» National project profile / approved by the Presidium of the RF Presidential Council on strategic development and national projects, meeting report No. 16 dated December 24, 2018. KonsultantPlus. Available at: http://www. consultant.ru/document/cons_doc_LAW_316096/(21.03.2020) (in Russian).
} 
received in each micro-environment allowing for time spent in each of them [13].

Micro-environment approach was first tested in risk assessment in 90-ties last century in the USA under the EPA supervision. At present this approach is a powerful tool for exposure assessment due to, among other things, use of databases maintained by state structures. Its application is included into health risk assessment regulations as it can be seen from description of software tools recommended by the EPA to be applied for taking micro-environment exposure into account: $« \ldots$ to assess health risks and impacts on the environment caused by exposure to «criterion» air contaminants (including photochemical oxidizers such as ozone) and toxic air contaminants» [13].

In Russia application of micro-environments in health risk assessment was described in 2002; however, later it was rather rarely used due to difficulties in obtaining necessary initial data, first of all, concentrations that produced effects on health and periods of time spent in each micro-environment [1]. An example of micro-environment approached being applied in exposure and risk assessment is a study on establishing a contribution made by a living environment into total carcinogenic risk taking into account contamination with carcinogens occurring in ambient air, air inside apartments, and public transport, and amount of time people spent in each microenvironment [14].

Programs recommended by the EPA to assess exposure taking micro-environments into account involve use of data on population provided by the EPA itself and the US Census Bureau.

To determine exposure value, one requires a great initial data array; considerable part of these data can be obtained either via specific research (questioning) or within a national census due to additional questionnaires applied in the process. For example, in the USA hapem 4 model can be applied to determine exposure duration for an individual; the model involves using activity patterns data and commuting patterns data [15].

An activity pattern is a consequence of discrete events (corresponds to time periods spent in different micro-environments) that describe a person's daily routines over a given day and his or her lifestyle. The pattern is characterized with different periods of times spent in each micro-environment mentioned in it. Hapem4 model uses data on different activities obtained from EPA complex database on human activities (CHAD) containing more than 22,000 person-day activity patterns [16].

A commuting pattern contains information on trips from home to work and back and it is important in situations when contaminants concentrations in micro-environments at work differ from those existing at homes. The task is solved via using a specialized database belonging to the US Census Bureau where there is a population number living in a given section that is assigned to each recorded section; that is, population that travels from a home section to a work one is clearly identified.

A similar micro-environment approach is implemented in TRIM.Expo (APEX) model for exposure assessment [13].

At present the RF Government is modernizing approaches to state regulation in environment protection sphere taking into account abundant international experience (EU countries and the USA) $)^{2,3}$.

A set of activities aimed at improving the state environmental policy has been developed; special attention here is paid to introduc-

\footnotetext{
${ }^{2}$ EU - Russia. The Cooperation program (Ecological standards harmonization II (ESHII)). The concluding technical report. Activity section 1 - Analyzing gaps in legislation; 1.4 - National strategy for ecological standards harmonization in Russia and Action plan for 2010-2025. Strategy-2020. Available at: http://2020strategy.ru/data/2011/07/26/1214727421/3.pdf (09.04.2020).

${ }^{3}$ Directive 2001/81/EC of The European Parliament and of the Council of 23 October 2001 on National Emission Ceilings for Certain Atmospheric Pollutants. Eurolex. Available at: https://eurlex.europa.eu/LexUriServ/LexUriServ.do?uri= CONSLEG:2001L0081:20090420:EN:PDF (26.03.2020).
} 
ing unified principles for emissions standardization basing on implementation of the best available technologies (BAT) ${ }^{4}$.

When implemented, the said standardization is assumed to make for a transition to more environmentally friendly and economically beneficial procedures for technical regulation and standardization of environmental contamination $^{5}[17,18]$. Given that, one should ensure that technologies already included or are planned to be included into BAT reference books ${ }^{6,7}$ are thoroughly analyzed before such inclusion takes place and probable negative impacts they may have on population health are to be assessed. That is, it is necessary to introduce certain procedures on assessing efficiency of BAT application for different industrial brunches taking into account residual health risks as well as target quality parameters of the environment (ambient air, water, and soil). BAT application, in its turn, will facilitate finding solutions to certain practical issues:

- introducing simpler procedures for accounting of priority contamination sources and contaminants;

- providing comparability of requirements for similar stationary sources;

- updating the state system for ecologic control;

- giving free access to data on BAT environmental efficiency.

When reforming a state system for environmental quality management, it is vital to remember that fixing standards for contaminants emissions into ambient air, even given all BAT parameters, doesn't ensure ambient air quality near emissions sources to correspond to levels that are safe for population health. In other words, fixing standards for contaminants emissions basing on BAT is not an alternative for conformity with hygienic standards for contaminants concentrations in ambient air and can't provide completely safe impacts on the environment and health in all cases $[15,16]$. A necessity to take this factor into account can also be found in international documents, for example, EU Directive or alterations to clauses in the US Clean Air Act $[16,19]$.

Therefore, when BAT parameters are implemented, it is necessary to obligatorily apply risk assessment methodology as it is only on its basis that one can determine whether there are no threats for population health (residual health risk levels) on a given territory after new procedures for emissions regulations have been implemented [19, 20].

Overall, a transition to technological regulation involving use of BAT parameters requires giving certain attention to such factors as legal aspects, economic advisability, health protection provided for specific population groups, roles played by all the counterparts participating in the process, costs and benefits analysis, and activities aimed at control and provision of decisions implementing $[15,16]$.

\footnotetext{
${ }^{4}$ On developing, fixing, and reviewing standards of the environment quality for chemical and physical parameters of the environment, as well as on approving on regulatory documents in environmental protection sphere that fix technological parameters for the best available technologies (together with «Provisions on developing, fixing, and reviewing standards of the environment quality for chemical and physical parameters of the environment»): The RF Government Order issued on February 13, $2019 \mathrm{~N}$ 149. Konsultant Plus. Available at: http://www.consultant.ru/document/cons_doc_LAW_318449/ (23.03.2020) (in Russian).

${ }^{5}$ On Approval of The rules for technological standards development: the Order by the RF Ministry of Natural Resources and the Environment issued on February 14, 2019 № 89. KODEKS: an electronic fund of legal and regulatory documents. Available at: http://docs.cntd.ru/document/542643374 (08.04.2020) (in Russian).

${ }^{6}$ On making alterations into The rules for determining a technology as the best available one as well as development, actualization and publication of reference and technical guides on the best available technologies: The RF Government Order issued on March 09, 2019 No. 250. Konsultant Plus. Available at: http://www.consultant.ru/cons/cgi/online.cgi?req=doc\&base= LAW\&n=319873\&fld=134\&dst=100001,0\&rnd=0.13379705097259964\#07000201105021768 (25.03.2020) (in Russian).

${ }^{7}$ On Approval of stage-by-stage schedule for actualization of reference and technical guides on the best available technologies: The RF Government Order issued on April 30, 2019 No. 866-r. Konsultant Plus. Available at: http://www. consultant.ru/document/cons_doc_LAW_324048/(11.04.2020) (in Russian).
} 
Implementation of such an approach will allow confirming efficiency of best available technologies introduced at productions; use of such technologies makes for preventing or reducing negative impacts on health and the environment down to acceptable levels.

Promising trends in developing health risk assessment and management mentioned in the present work are included into the Rospotrebnadzor's specialized scientific-research program for 2021-2025.

Funding. The research was not granted any sponsor support.

Conflict of interests. The authors declare there is no any conflict of interests.

\section{References}

1. Onishchenko G.G., Novikov S.M., RakhmaninYu.A., Avaliani S.L., Bushtueva K.A. Osnovy otsenki riska dlya zdorov'ya naseleniya pri vozdeistvii khimicheskikh veshchestv, zagryaznyayushchikh okruzhayushchuyu sredu [Basics of health risk assessment under exposure to chemicals that pollute the environment]. In: Yu.A. Rakhmanin, G.G. Onishchenko eds. Moscow, Nauchno-issledovatel'skii institute ekologii cheloveka i gigieny okruzhayushchei sredy imeni A.N. Sysina Publ., 2002, 408 p. (in Russian).

2. Novikov S.M., Shashina T.A., Dodina N.S., Kislitsin V.A., Skovronskaya S.A., Matsyuk A.V., Panchenko S.V., Arakelyan A.A. The experience of empirical research on comparative assessment of radiation and chemical health risks due to exposure to environmental factors. Gigiena i sanitariya, 2019, vol. 98, no. 12, pp. 1425-1431 (in Russian).

3. Revich B.A., Shaposhnikov D.A., Pershagen G. New epidemiological model for assessment of the impact of extremely hot weather and air pollution on mortality (in case of the Moscow heat wave of 2010). Profilakticheskaya meditsina, 2015, vol. 18, no. 5, pp. 29-33 (in Russian).

4. IPCS (International Program on Chemical Safety), 2014. Guidance Document on Evaluating and Expressing Uncertainty in Hazard Characterization. World Health Organization. Available at: http://www.who.int/ipcs/methods/harmonization/areas/hazard_assessment/en/ (01.04.2020).

5. National Research Council. Science and Decisions: Advancing Risk Assessment. Washington, DC, The National Academies Press Publ., 2009, 423 p.

6. Rodricks J.V., Levy J.I. Science and Decisions: Advancing Toxicology to Advance Risk Assessment. Toxicological Sciences, 2013, vol. 131, no. 1, pp. 1-8. DOI: 10.1093/toxsci/kfs246

7. Rekomendatsii po ispol'zovaniyu funktsii «kontsentratsiya - effekt» v otnoshenii tverdykh chastits, ozona i dioksida azota dlya analiza zatrat i vygod [Recommendations on use of «concentration - effect» function regarding particulate matter, ozone and nitrogen dioxide in analyzing costs and benefits]. Copenhagen, World Health Organization, 2015, 66 p. (in Russian).

8. Chiu W.A., Slob W.A. Unified Probabilistic Framework for Dose-Response Assessment of Human Health Effects. Environ Health Perspect, 2015, vol. 123, no. 12, pp. 1241-1254. DOI: 10.1289/ehp.1409385

9. Gehlhaus M.W., Gift J.S., Hogan K.A., Kopylev L., Schlosser P.M., A.-Kadry R. Approaches to cancer assessment in EPA's Integrated Risk Information System. Toxicol. Appl. Pharmacol., 2011, vol. 254, no. 2, pp. 170-180. DOI: 10.1016/j.taap.2010.10.019

10. Slob W., Bakker M.I., Biesebeek J.D.T., Bokkers B.G.H. Exploring the Uncertainties in Cancer Risk Assessment Using the Integrated Probabilistic Risk Assessment (IPRA) Approach. Risk Analysis, 2014, no. 34, pp. 1401-1422. DOI: 10.1111/risa.12194

11. Slob W., Setzer R.W. Shape and steepness of toxicological dose-response relationships of continuous endpoints. Critical Reviews in Toxicology, 2014, vol. 44, no. 3, pp. 270-297. DOI: 10.1111/risa.12194

12. Hardy A., Benford D., Halldorsson T., Jeger M.J., Knutsen K.H., More S., Mortensen A. [et al.]. U.S. EPA. Benchmark Dose Technical Guidance. EFSA Journal, 2017, vol. 15, no. 1 (4658), pp. 41. DOI: $10.2903 /$ j.efsa.2017.4658

13. Air: Fate, Exposure, and Risk Analysis (FERA). EPA. Available at: https://www.epa.gov/fera/ $(10.08 .2020)$.

14. Gubernskii Yu.D., Novikov S.M., Kalinina N.V., Matsyuk A.V. Otsenka riska vozdeistviya na zdorov'e naseleniya khimicheskikh veshchestv, zagryaznyayushchikh vozdukh zhiloi sredy [Assessing 
risks of effects produced on population health by chemicals that pollute air in residential areas]. Gigiena $i$ sanitariya, 2002, no. 6, pp. 27-30 (in Russian).

15. Further Technical Details about HAPEM4. EPA. Available at: https://archive.epa.gov/airtoxics/ nata/web/html/hapem4followup2.html (10.08.2020).

16. EPA's Consolidated Human Activity Database. EPA. Available at: https://www.epa.gov/ healthresearch/epas-consolidated-human-activity-databasehttps://www.epa.gov/fera/ (10.08.2020).

17. Sorokin N.D. Tekhnologicheskie normativy, tekhnologicheskie pokazateli i markernye veshchestva [Technological standards, technological parameters, and marker substances]. Ekologiya proizvodstva, 2019, no. 9, pp. 32-41 (in Russian).

18. Shchelchkov K.A., Volosatova M.A., Grevtsov O.V. Osnovnye aspekty primeneniya informatsionno-tekhnicheskikh spravochnikov po NDT [Basic aspects related to applying reference and technical guides on BAT]. Ekologiya proizvodstva, 2019, no. 5, pp. 20-26 (in Russian).

19. Clean. Air. Act., 1990. EPA. Available at: http://www.epa.gov/air/caa/ (10.04.2020).

20. Avaliani S.L., Mishina A.L. Harmonization of approaches to management of air quality. Zdorov'e naseleniya i sreda obitaniya, 2011, vol. 216, no. 3, pp. 44-48 (in Russian).

Rakitskii V.N., Kuz'min S.V., Avaliani S.L., Shashina T.A., Dodina N.S., Kislitsin V.A. Contemporary challenges and ways to improve health risk assessment and management. Health Risk Analysis, 2020, no. 3, pp. 22-28. DOI: 10.21668/health.risk/2020.3.03.eng

Received: 28.08 .2020

Accepted: 01.09.2020

Published: 30.09.2020 